\title{
Bone Transport Over Radius Over Ulna: A Case Report
}

\author{
Muralliraj Etiapan*, Sashitharan and Narinder Singh Gill \\ Department of Orthopedic, Hospital Seberang Jaya, Malaysia \\ Submission: August 16, 2020; Published: August 25, 2020 \\ *Corresponding author: Muralliraj Etiapan, Department of Orthopedic, Hospital Seberang Jaya, Malaysia
}

\begin{abstract}
Consequential bone disappearance in the lower arm including both the radius and ulna is a troublesome issue to oversee. Similarly, infected non-union with bone defects is difficult to manage. The practical result might be restricted because of loss of expert and supination. We present a situation where noteworthy bone loss of both the range and the ulna in an adult which was effectively recreated utilizing segmental bone transport. The radius and ulna were shipped autonomously from one another to attempt to look after capacity. This report features the viability of distraction osteogenesis in the administration of lower arm bones deformity auxiliary to infection and thus a sensible utilitarian outcome was accomplished.
\end{abstract}

Keywords: Bone disappearance; Infected non-union; Supination; Segmental bone transport; Distraction osteogenesis

\section{Introduction}

Critical segmental bone disappearance in the lower arm is a troublesome clinical substance to treat. Techniques depicted in writing incorporate interposition grafting, twofold barrel free fibula reproduction, actuated film strategies, and changing over to a solitary bone lower arm by setting up a cross union [1]. Despite the fact that the congruity of bone can be reestablished, the complex relationship of the radius and ulna might be interrupted, prompting a constraint of pro and supination [2]. Distraction osteogenesis was created by Gavriil Abramovich Ilizarov from Russia in 1951 and it is a weakening and tedious strategy in orthopedics [3]. Reproducing the radius and ulna freely with distraction osteogenesis bone transport has the hypothetical bit of leeway of keeping up the unpredictable connection between the radius and ulna in the lower arm. On a basic level this ought to give the capacity to keep up a proportion of professional and supination after remaking [4].

\section{Case Report}

A 50-year-old Malay right hand dominant gentleman involved in motor-vehicle accident on $27^{\text {th }}$ June 2016 and sustained open fracture over right proximal radius and ulnar (Gustillo 2). Wound debridement and primary fixation over radius and ulnar were done within 6 hours post-accident. Unfortunately, patient developed infective non-union with exposed implant (figure 1). Patient underwent second round of wound debridement and hardware removal. The anticipated bone resection was $4 \mathrm{~cm}$. Patient was giv en option between Masquelet and distraction osteogenesis with a thorough explanation of both procedures. After giving serious and much thought, patient agreed for the later (figure 2). Bone transport was successful at the ulna bone. Distraction started on day 7 post operation. Amount of distraction was $0.25 \mathrm{~mm}$ per day 6 hourly. Days of distraction was 40days. Meanwhile, days of consolidation was 80days and patient was kept on monotube fixator for 127 days (figure 3). Patient was given option for low profile plate for consolidation, but he refused. Later, patient developed pin site infection (C-Otterburn grade 2 ) and was treated for 2 episodes with oral antibiotics and proper dressing. Radius bone required bone grafting over docking site (figures 4-7).

\section{Discussion}

Infected non-unions are difficulties that are uncommon however have enormous effect both on the patient and on the specialist's abilities. Looking into the literature, most reports on the treatment of infected non-unions allude to the lower extremity, particularly the tibia. Contaminated nonunion in the furthest point is an uncommon occasion, particularly in the lower arm. Such patients generally have had various past surgical intervention, bringing about bone imperfections and soft tissue compromise [5]. Infected non-unions of lower arm bones are once in a while experienced with not many reports in writing. These are seen particularly after treatment of ignored cases or cases with history of smoking, liquor abuse or other co-morbidities. 


\section{Orthopedics and Rheumatology Open Access Journal (OROAJ)}

The board alternatives incorporate arranged debridement and interior obsession after control of disease or single organized debridement and outside fixator. Despite the fact that cases are accounted for independently, and as a feature of bigger arrangement, a positive rule is hard to build up [6]. In the current examination, all the patients were treated by bone transport. To maintain a strategic distance from postponed bone-recuperating, total fix of the disease is the pillar of treatment in infected non- unions. The most significant rule in destroying osteomyelitis is exhaustive and sufficient debridement until live and draining bone is reached. In the creator's assessment, effective treatment of infected nonunion frequently consolidates radical debridement of the septic bone and delicate tissue notwithstanding utilization of stable obsession to improve delicate tissue recuperating and bone association $[1,7]$.

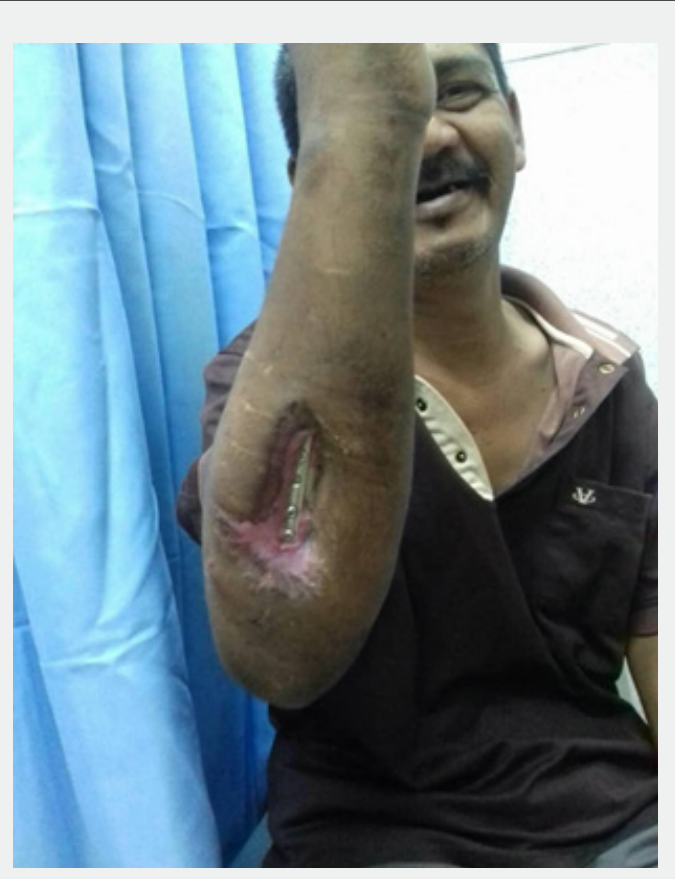

Figure 1: Wound break down post primary fixation with implant exposed.

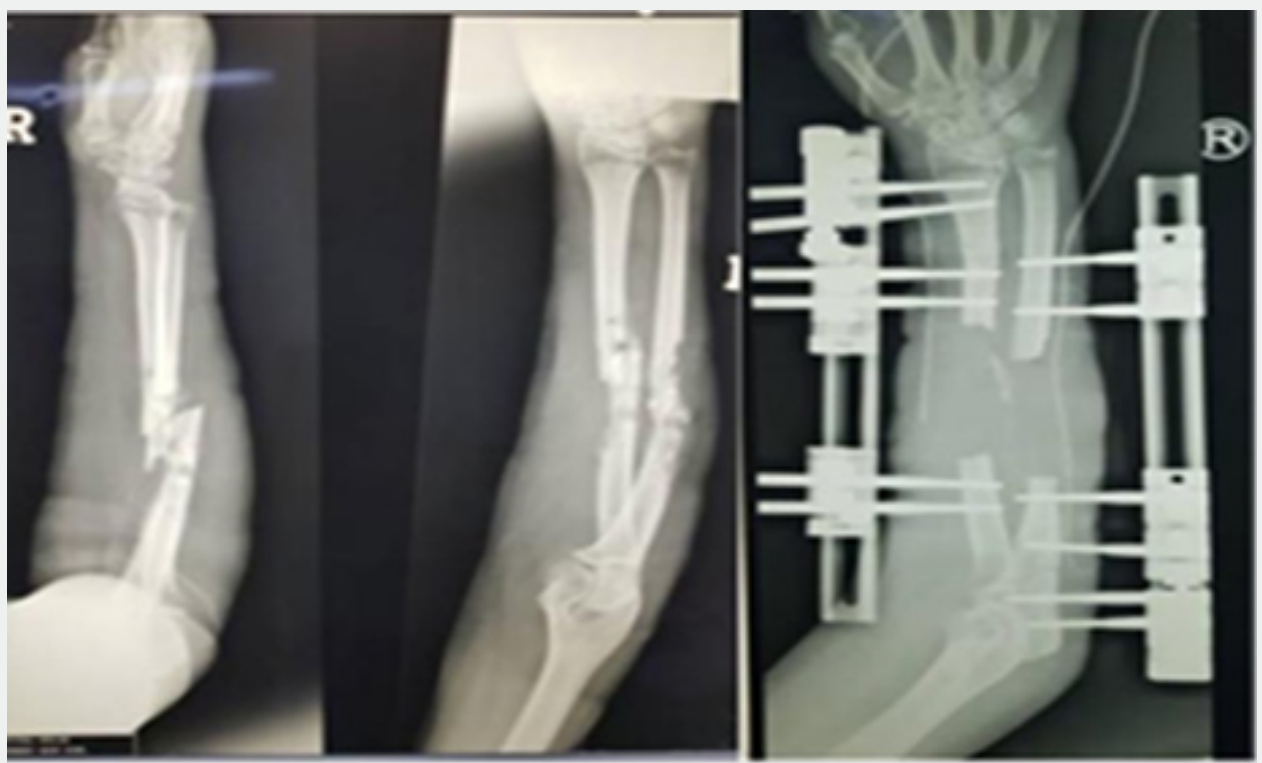

Figure 2: X-rays of (i) area after plate removal with evidence of infective non-union, (ii) area of infective non-union resected and (iii) post distraction osteogenesis. 


\section{Orthopedics and Rheumatology Open Access Journal (OROAJ)}
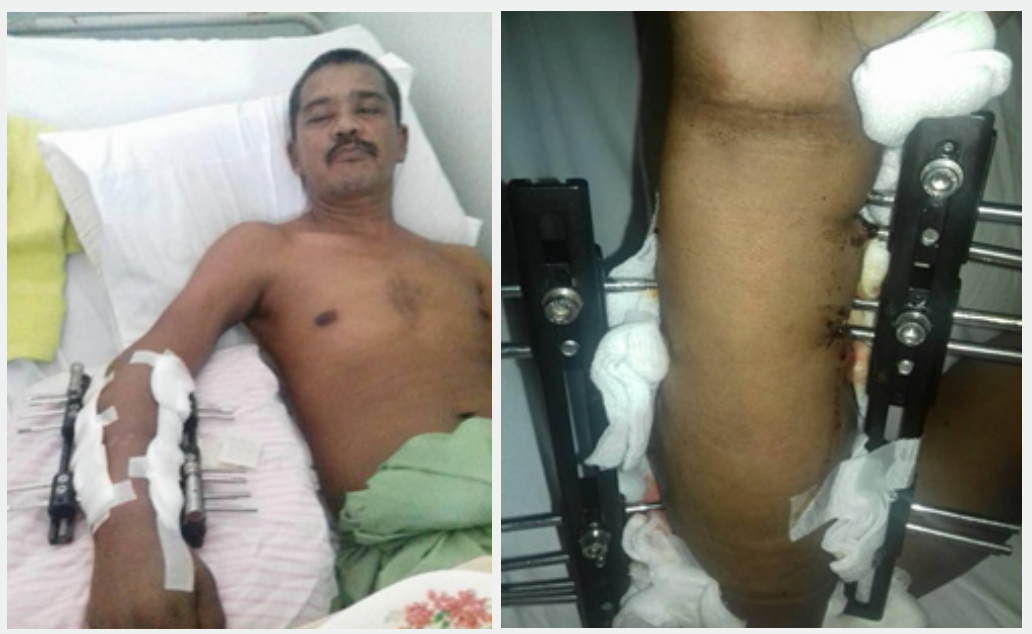

Figure 3: Post monotube fixation over radius/ulna

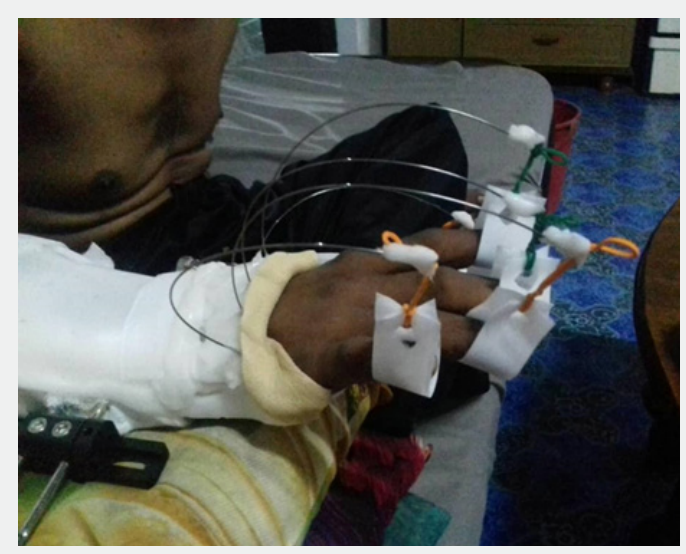

Figure 4: Patient put on dynamic hand splint to prevent wrist and hand stiffness post operation.

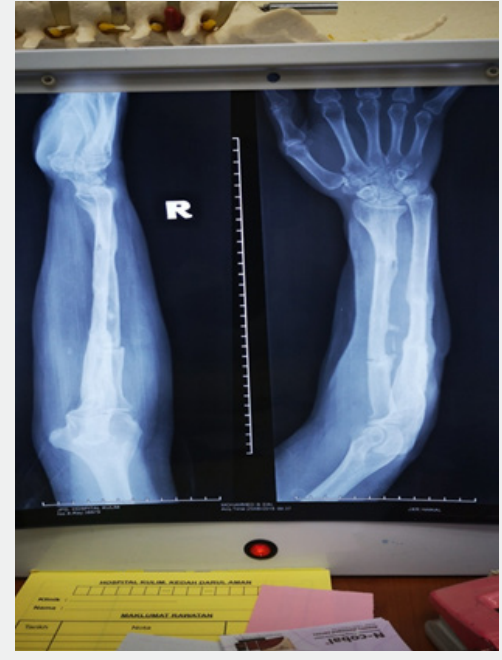

Figure 5: Post-operative 6 months showing good callous formation. 


\section{Orthopedics and Rheumatology Open Access Journal (OROAJ)}

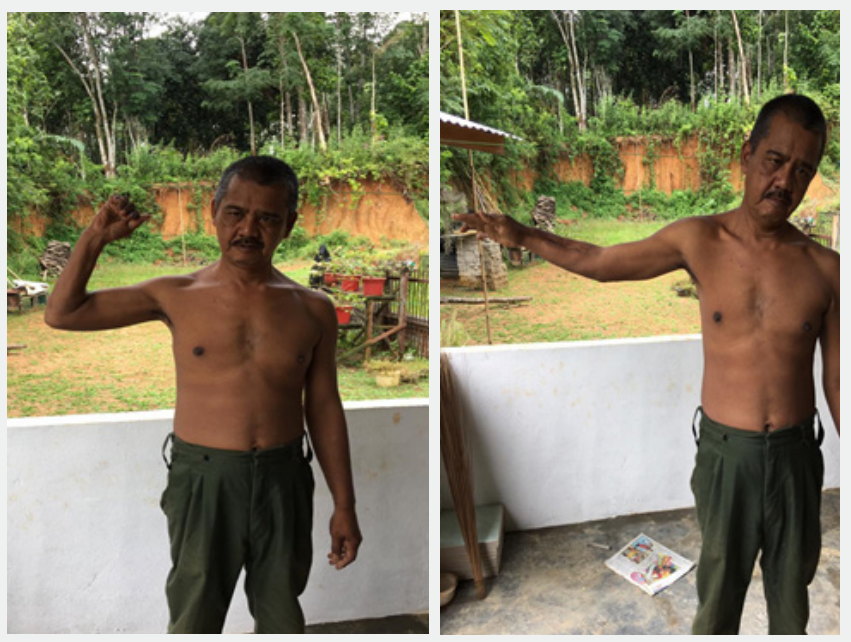

Figure 6: Functional range of motion of the elbow joint 1year 6months.
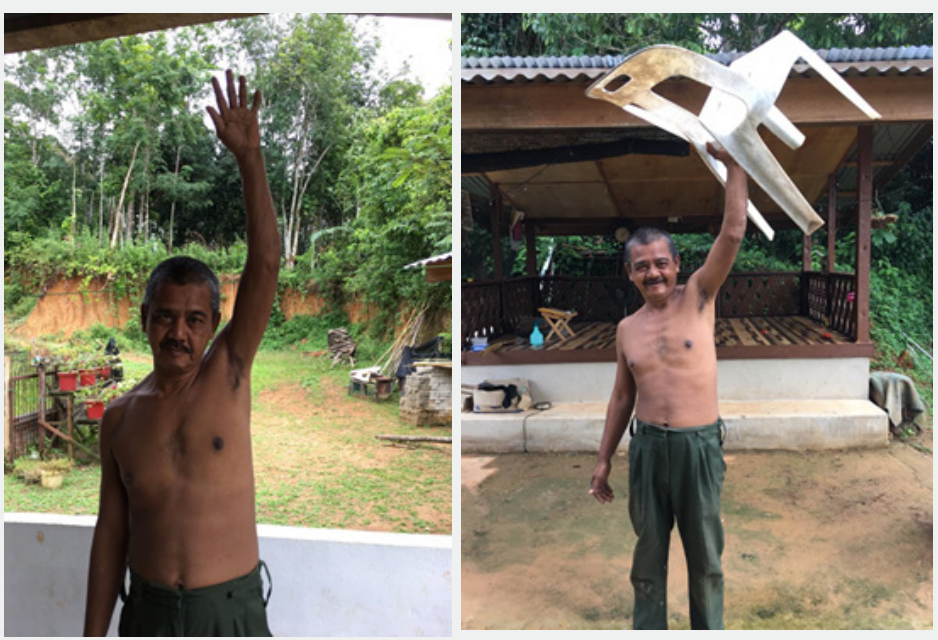

Figure 7: Good functional outcome of the wrist and shoulder joint post operatively.

So, the extreme expulsion of the necrotic and infected parts of both bone and delicate tissues speaks to the most significant component for the achievement of treatment by pressure interruption method in serious tainted nonunion of the ulna or sweep. Free and sequestrated bone ought to be additionally evacuated. In the current investigation, the contamination had been controlled in all the patients. It is a basic issue that whether the extended region will be contaminated optionally when the bone is being debrided and extended in patients with contaminated nonunion and bone deformity $[1,7]$.

As far as anyone is concerned, there is no report on extended territory disease in contaminated nonunion patients after at the same time bone vehicle and debridement. In the current examination, there is likewise no protracted region disease. The creators received a far-off osteotomy to begin the interruption and adequate waste in infective site. The osteotomy was acted in the solid bone a long way from the tainted issue that remains to be worked out acceptable vascularity for solidification $[5,8]$. Distraction osteogenesis was the better option. It is involving adjacent 2 bones with bone loss. It provides limited dissection and controlled resection. It has more reliability of bone stability. Allows desired correction because both transport rhythm and direction can be adjusted.

\section{Conclusion}

Infected non-union with bone defects is difficult to manage. This report highlights the effectiveness of distraction osteogenesis in the management of forearm bones defect secondary to infection. Effective reconstructive therapy and rehabilitation can result in good clinical outcome. 


\section{References}

1. Kesemenli C, Subasi M, Kirkgoz T, Kapukaya A, Arslan H (2001) Treatment of Traumatic Bone Defects. Acta Orthop Belg 67(4): 380-38 6.

2. Birkholtz F, Greyling P (2016) Independent segmental bone transport of the radius and ulna: A case report. SA Orthop J.

3. Subramaniam KR, Ed Simor Khan, Ahmad Hafiz Zulkifly, Ashwini Sood (2018) Strontium Ranelate Reduces Duration of Consolidation Phase in Distraction Osteogenesis: 2 Case Reports. Orthop Res Online J 3(5).

4. Naalla R, Chauhan S, Dave A, Singhal M (2018) Reconstruction of post-traumatic upper extremity soft tissue defects with pedicled flaps: An algorithmic approach to clinical decision making. Chinese J Traumatol - English Ed. Chinese Journal of Traumatology 21(6): 338-351.
5. Liu T, Liu Z, Ling L, Zhang X (2013) Infected forearm nonunion treated by bone transport after debridement. BMC Musculoskelet Disord 27(2013).

6. Parihar M, Ahuja D (2012) Infected Nonunion of Radius and Ulna Strategy of Approach. J Orthop case reports 2(4): 26-31.

7. Kloen P, Wiggers JK, Buijze GA (2010) Treatment of diaphyseal nonunions of the ulna and radius. Arch Orthop Trauma Surg 130(12): 1439-1445.

8. Akdemir M, Biçen Ç, Türken MA, Turan AC, Arıkan A (2020) Treatment of femoral defective osteomyelitis with minimal invasive plates. Trauma Case Reports 28: 100317.

\section{Your next submission with Juniper Publishers will reach you the below assets}

- Quality Editorial service

- Swift Peer Review

- Reprints availability

- E-prints Service

- Manuscript Podcast for convenient understanding

- Global attainment for your research

- Manuscript accessibility in different formats

( Pdf, E-pub, Full Text, Audio)

- Unceasing customer service

Track the below URL for one-step submission https://juniperpublishers.com/online-submission.php 